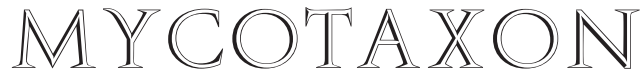

Volume 122, pp. 145-156

http://dx.doi.org/10.5248/122.145

October-December 2012

\title{
Geastrum species of the La Rioja province, Argentina
}

\section{Francisco KuhaR ${ }^{\star}$, Valeria Castiglia \& Leandro Papinutti}

Laboratorio de Micología Experimental, DBBE, Facultad de Ciencias Exactas y Naturales, Ciudad Universitaria, (C1428EHA) Ciudad de Buenos Aires, Argentina.

*Correspondence to: fkuhar@yahoo.com.ar

Abstract-A survey of Geastrum species from arid lands in the La Rioja province (northwestern Argentina) recovered fourteen species previously unreported from the province: G. arenarium, G. campestre var. famatinum, G. corollinum, G. fimbriatum, G. floriforme, G. glaucescens, G. hieronymi, G. aff. lloydianum, G. pampeanum, G. pampeanum var. pallidum, G. parvistriatum, G. rufescens, G. saccatum, and G. schmidelii. Of these, new records are G. corollinum for Argentina, G. arenarium for South America, and G. parvistriatum for the Americas, and G. campestre var. famatinum is proposed as a new variety. Each taxon is described, and photographs of basidiomes and SEM micrographs illustrating spores are provided for selected taxa.

KEY WORDs - Geastrales, mycobiota, Phallomycetidae, taxonomy

\section{Introduction}

The genus Geastrum (earthstars) is characterized by subspherical to spherical basidiomes having a central axis (columella) surrounded by a mass of fertile tissue (gleba) contained within an inner (endoperidium) and outer (exoperidium) layer. Spores are liberated through a single apical pore (in the endoperidium) surrounded by a highly variable structure called the peristome. At maturity, the exoperidium splits into a variable number of rays, which give Geastrum basidiomes their characteristic star-shape. These exoperidial rays serve to protect the endoperidial body and facilitate spore dispersal. With their unique morphology, Geastrum species represent the evolution of one of the more specialized basidiome forms found among the gasteroid fungi.

The present paper focuses on Geastrum species that were collected during survey of gasteroid fungi of the La Rioja province of northwestern Argentina. La Rioja belongs to the Monte biogeographical province, which is defined as a xeric biome (80-200 $\mathrm{mm}$ annual rainfall) based on its vegetation and 
physiognomy (Roig 1998; Roig-Juñent 2001). The predominant vegetation is a shrub steppe, which is a characteristic endemic flora mainly represented by vascular plant species in the Zygophyllaceae (e.g., Larrea, Bulnesia, and Plectrocarpa). Each Geastrum taxon recovered in the survey is described and discussed, and selected taxa are illustrated.

\section{Materials \& methods}

This work is based on specimens collected by L. Papinutti and G. Rolón and deposited in the University of Buenos Aires Herbarium (BAFC). Capillitial threads and spores were observed under light (mounted in $\mathrm{KOH} 3 \% \mathrm{w} / \mathrm{v}$ ) or scanning electron (Zeiss DSM 982 Gemini) microscopy. At least 20 measurements were made to estimate the size of microscopic and macroscopic elements. Macroscopic measures were made on dry basidiomes. All spore measurements citing the diameter include the ornamentation. Colors were described in well-preserved dry specimens and indicated following Maerz \& Paul (1930). Bates (2004), Dominguez de Toledo (1989), Sunhede (1989), Soto \& Wright (2000), Ponce de Leon (1968), Calonge (1998) and Zamora \& Calonge (2007) were used as standard references in the determination of collections.

\section{Taxonomy}

Geastrum arenarium Lloyd, Geastrae: 28 (1902, as"Geaster arenarius"). Figs 1c, 2a Mature basidiomes 20-30 $\mathrm{mm}$ wide; exoperidium arched, splitting in 10-12 subequal arching, revolute, hygroscopic rays; mycelial layer encrusting fine particles of debris and sand; fibrous layer creamy white (2A1); pseudoparenchymatous layer whitish to pallid brown (14C7) when immature, rimulose in age; endoperidial body 5-12 mm wide almost sessile, globose, slightly pruinose, pallid brown (14C7); apophysis reduced; peristome fibrillose, conical, delimited, darker, concolorous, or lighter than the surrounding endoperidium; gleba brown (7H10), cottony.

Spores globose, 2.5-3.7 $\mu \mathrm{m}$ wide, verrucose, with a short apiculus that is difficult to discern due to the dense covering of mammiform verrucae.

SPECIMEN EXAMINED-ARGENTINA. LA Rioja: Miranda, $28^{\circ} 28^{\prime} 33.68^{\prime \prime} \mathrm{S}$ $67^{\circ} 42^{\prime} 27.55^{\prime \prime} \mathrm{W}$, gregarious on abundant leaf litter under Prosopis sp. (Mimosaceae), 27.III.2008, leg. L. Papinutti \& G. Rolón (BAFC 51925).

Comments-Although most basidiomes exhibited hygroscopic rays, subhygroscopic rays were also observed. A very short stalk was observed in some dry specimens similar to North American material described by Bates (2004; referred to by the author as " \pm sessile"), while other specimens were entirely sessile. Geastrum arenarium may be confused with other hygroscopic species, G. corollinum and G. floriforme, from La Rioja. However, these taxa have larger spores than G. arenarium and a mycelial layer not strongly encrusted with sand and debris. This is the first record of this species for Latin America. 


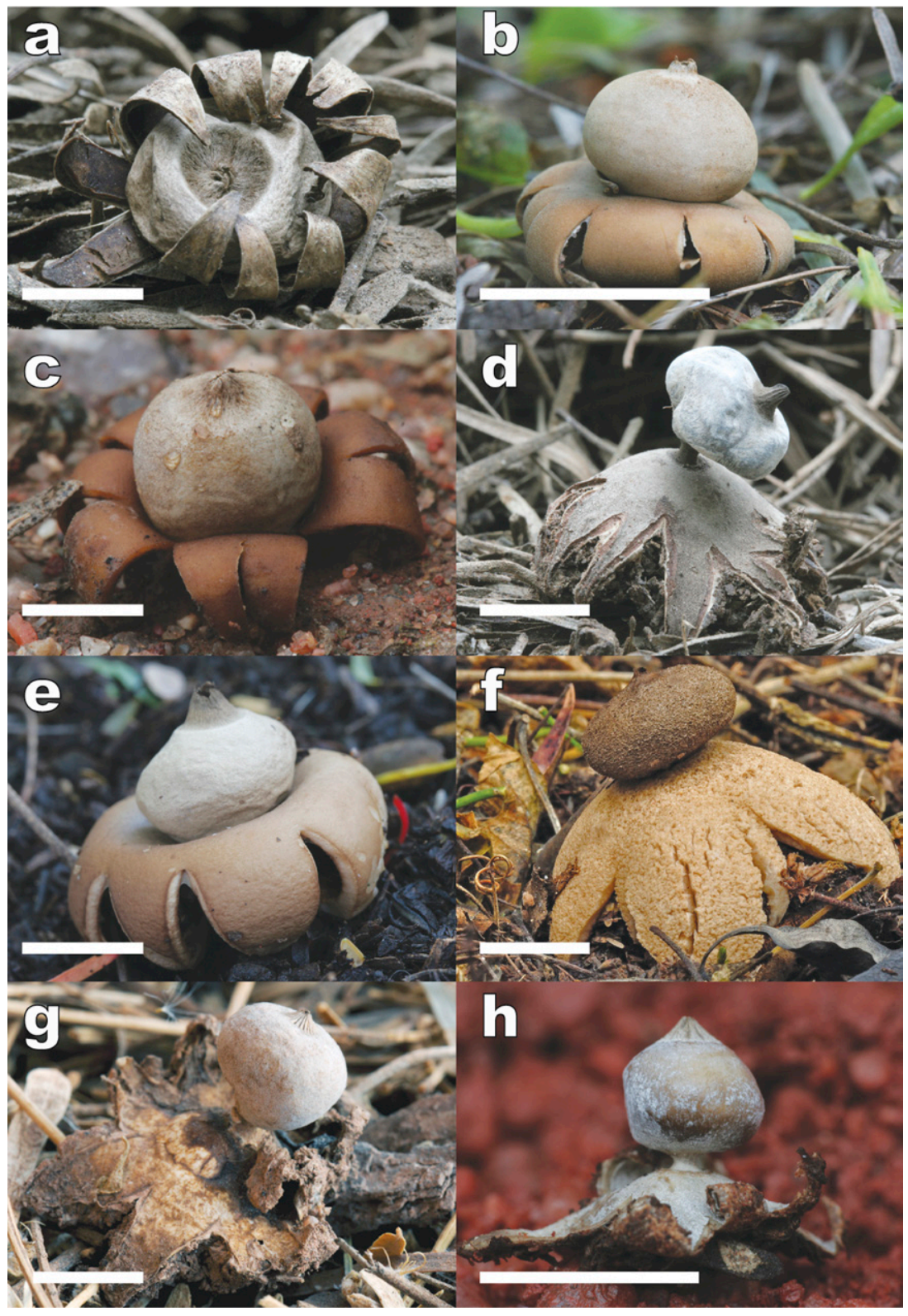

Figure. 1: a. G. corollinum. b. G. floriforme. c. G. arenarium. d. G. parvistriatum. e. G. saccatum. f. G. hieronymi. g. G. campestre var. famatinum. h. G. glaucescens. Scale bars $=1 \mathrm{~cm}$. 


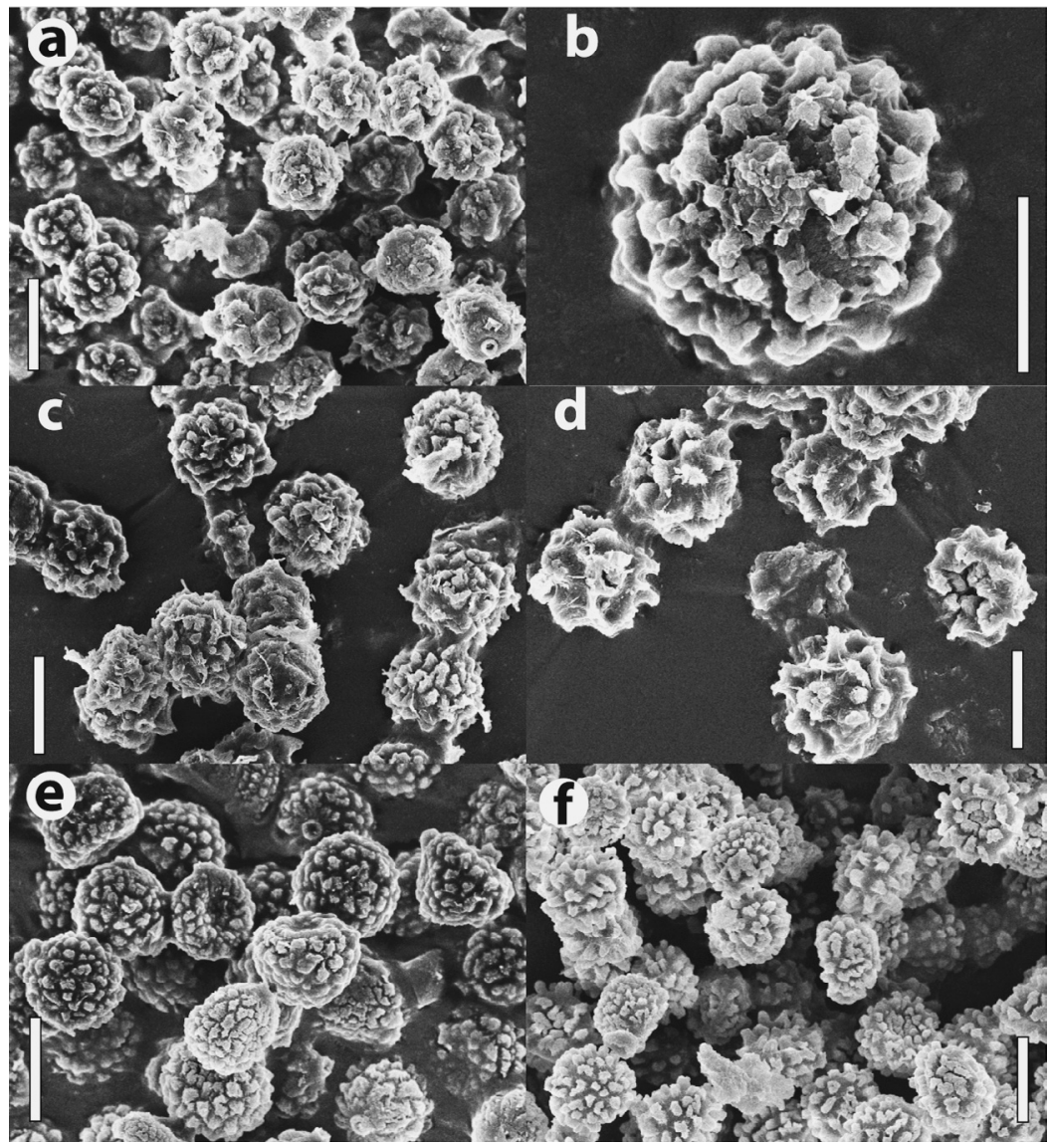

FIGURE. 2: SEM micrographs of spores. a. G. arenarium. b. G. hieronymi. c. G. glaucescens. d. G. parvistriatum. e. G. aff. lloydianum. f. G. pampeanum var. pampeanum. Scale bars: a, c-f = 4 $\mu \mathrm{m} ; \mathrm{b}=2 \mu \mathrm{m}$.

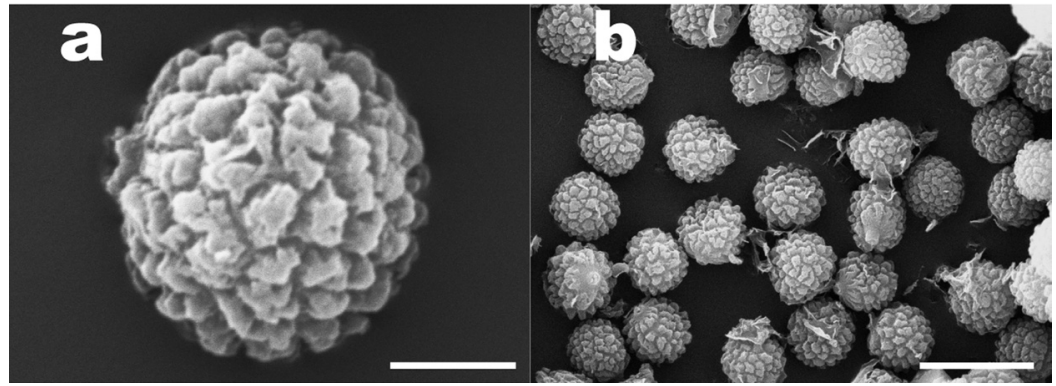

FIGURE. 3: SEM micrographs of G. campestre var. famatinum spores. Scale bars: $\mathrm{a}=1 \mu \mathrm{m} ; \mathrm{b}=5 \mu \mathrm{m}$. 
Geastrum campestre var. famatinum Kuhar \& Papinutti, var. nov.

FIGs 1g, 3 MrcoBank MB 563048

Differt a typo Geastri campestris magnitudine sporarum valde minore.

Type: Argentina. La Rioja: Famatina Department, Pituil, 28³4'47.94"S 67²7'59.42"W under Prosopis sp., 27.III.2008, leg. L. Papinutti \& G. Rolón, (holotype,, BAFC 51926).

ЕтумоLоgy: from the name of the geographic department of the type locality.

Expanded basidiomes 20-35 mm wide; exoperidium arched, splitting in 9-12 subequal rays, revolute and curving under the endoperidial body, weakly hygroscopic; mycelial layer encrusted with abundant debris, peeling off toward the ray tips with age but persisting in the rest of the endoperidium; fibrous layer light colored (12G7) and smooth; pseudoparenchymatous layer dirty dark brown (8E8), peeling off of the fibrous layer in an irregular manner; endoperidial body 10-18 mm wide globose with a very short stalk, verrucose and slightly pruinose, grey (14A3), laterally compressed in some specimens; apophysis visible; peristome definite, plicate, conic, concolorous with the surrounding endoperidium; gleba dark brown (8A11), cottony.

Spores globose, 3.5-4.2 $\mu \mathrm{m}$ wide, verrucose.

Comments-This collection agrees very precisely with published descriptions of G. campestre, but the spores are much smaller than those measured by Sunhede (1989; 6.5-8 $\mu \mathrm{m})$, Ponce de León (1968; 5-6 $\mu \mathrm{m})$ and Bates (2004; 6.4-8 $\mu \mathrm{m})$. Domínguez de Toledo (1989), in her prospection of Córdoba and La Pampa provinces (Argentina), reported some collections of G. campestre having, on average, half the spore size than is typical for this species. Soto \& Wright (2000), who described very similar basidiomes, treated them as G. ambiguum due to the smaller spore size. Sunhede (1989), who carefully studied type material of G. ambiguum deposited at Kew, concluded that it is a synonym of $G$. campestre. Another similar species is $G$. smithii, which differs from $G$. campestre in having spores more densely covered with shorter verrucae, a rimose pseudoparenchymatous layer, and a peristome surrounded by a depressed area. The granulose endoperidium is a striking characteristic that clearly differentiates $G$. campestre from other similar species. Since the La Rioja collection fits the macromorphological description of G. campestre reported in Sunhede (1989) but with considerably smaller spores, we propose this as a new variety.

Geastrum corollinum (Batsch) Hollós, Gasteromyc. Ungarns: 62 (1904, as “Geaster corollinus").

Fig. 1a

Basidiomes small to very small 6-19 mm wide; exoperidium saccate to slightly arched, very hard in old specimens, splitting into 8-11 strongly hygroscopic rays that cover the endoperidial body; mycelial layer encrusting debris but soon peeling off; fibrous layer whitish grey (5A8); pseudoparenchymatous layer very 
persistent, turning brown to dark brown (8L6) in old specimens; endoperidial body sessile, globose, greyish beige (12B4); peristome fibrillose, delimited; mature gleba brown (7A11).

Spores globose, 4.0-5.0 $\mu \mathrm{m}$ wide, verrucose, with some verrucae coalescing at their apices; apiculus distinct.

\begin{abstract}
Specimens EXAmined-ARGENTINA. LA Rioja: Santa Cruz, 28 $28^{\circ} 35.11^{\prime \prime} S$ $67^{\circ} 41^{\prime} 54.45^{\prime \prime} \mathrm{W}$, gregarious on abundant leaf litter under Prosopis sp., 27.III.2008, leg. L.

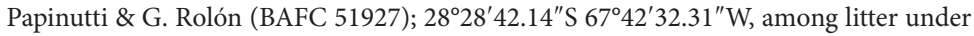
Prosopis sp., 27.III.2008, leg. L. Papinutti \& G. Rolón (BAFC 51928); 28²8'42.15"S $67^{\circ} 42^{\prime} 49.79^{\prime \prime} \mathrm{W}$, on abundant leafy litter under Prosopis sp. near a dry river, 28.III.2008, leg. L. Papinutti \& G. Rolón (BAFC 51929).
\end{abstract}

Comments - Although fruit body size is homogeneous within each of our collections, the variation among different collections is high. Sunhede (1989) clearly illustrates the variability of this character. Geastrum corollinum and G. glaucescens are the most frequent species found in our survey of this province. This is the first report of G. corollinum for Argentina.

Geastrum fimbriatum Fr., Syst. Mycol. 3(1): 16 (1829, as “Geaster fimbriatus").

Basidiomessmall to medium sized 20-25 mm wide; exoperidium often saccate, splitting from about the middle in 6-10 non-hygroscopic to sub-hygroscopic rays with light margins; mycelial layer encrusting debris but peeling off in some specimens; fibrous layer light beige (4C7) on both sides in fresh specimens, becoming denuded and whitish in older ones; pseudoparenchymatous layer becoming brownish in age (7A11); endoperidial body $9-11 \mathrm{~mm}$ wide greyish brown (8C11), sessile, globose to depressed globose; peristome fibrillose, not delimited, sometimes slightly protruding; gleba brown (8L6).

Spores globose, 3.5-4.0 $\mu \mathrm{m}$ wide, verrucose with $\leq 0.4 \mu \mathrm{m}$ long columnar verrucae; capillitial hyphae thick walled.

SPECIMEN EXAMINED-ARGENTINA. LA Rioja: Guanchín, 2909'40.98"S $67^{\circ} 39^{\prime} 40.37^{\prime \prime} \mathrm{W}$, gregarious, on finely particulated debris of diverse plant species, 27.III.2008, leg. L. Papinutti \& G. Rolón (BAFC 51930).

Comments-Geastrum fimbriatum, one of the most widely distributed species in the genus, has been cited in Europe (Sunhede 1989; Calonge 1998), North America (Bates 2004), and Latin America (Leite et al. 2007; Pereira et al. 2009; Calonge et al. 2005), including Argentina's Buenos Aires province (Soto \& Wright 2000). This is the first record for La Rioja province.

Geastrum floriforme Vittad., Monog. Lycoperd.: 23 (1842, as “Geaster floriformis”).

Fig. 1b

Basidiomes small to very small, 5-10 $\mathrm{mm}$ wide, hypogeous prior to opening; exoperidium saccate to slightly arched when fresh, very hard when dry, splitting in about 6-11 strongly hygroscopic rays, these covering the 
endoperidial body in the dry state; mycelial layer encrusting debris but peeling off early in the development of the basidiome; fibrous layer greyish (4A1); pseudoparenchymatous layer very persistent, turning brown (8L6) to dark brown in old specimens; endoperidial body 3-6 $\mathrm{mm}$ wide, sessile light brown (14E7); peristome fibrillose not delimited; apophysis absent; gleba brown (7A11).

Spores globose, 5.0-5.5 $\mu \mathrm{m}$ wide, verrucose with short irregularly shaped verrucae; apiculus distinct.

Specimen EXAmined- ARGENTINA. LA Rioja: Santa Cruz, 29 20'45.54"S $67^{\circ} 42^{\prime} 22.16^{\prime \prime} \mathrm{W}$, on Larrea divaricata and Baccharis sp. leaf litter, 27.III.2008, leg. L. Papinutti \& G. Rolón (BAFC 51931).

Comments-In Argentina G. floriforme was documented from Córdoba and Catamarca provinces (Domínguez de Toledo, 1989) and Buenos Aires province (Soto \& Wright 2000). This is a first record for La Rioja.

Geastrum glaucescens Speg., An. Mus. Nac. Bs. As. 23: 14

(1912, as "Geaster").

FIGs 1h, 2c

Mature basidiomes 11-24 mm wide; exoperidium weakly arched, splitting in 9-10 subequal involute sub-hygroscopic rays; mycelial layer encrusted with fine debris, fibrous layer whitish; pseudoparenchymatous layer greyish beige in age (5A8), breaking tangentially at the base of the rays; pseudoparenchymatous layer and endoperidial body covered with abundant persistent white mesoperidial matter; endoperidial body 5-10 mm wide, stalked, globose, surface slightly pruinose, concolorous with the inner exoperidial surface (7A10 to 6A7); stalk white, $1 \mathrm{~mm}$ long; apophysis absent; peristome plicate, conical, delimited, concolorous to dark brown at the very tip; gleba brown (7H12), cottony.

Spores globose, 3.5-4.5 $\mu \mathrm{m}$ wide, with a short apiculus that is difficult to discern due to the covering of short mammiform verrucae.

\footnotetext{
Specimens eXAmined- ARGENTINA. LA Rioja: Santa Cruz, 29²0'45.54"S $67^{\circ} 42^{\prime} 22.16^{\prime \prime} \mathrm{W}$, solitary, on leaf litter of Larrea divaricata and Baccharis sp., 27.III.2008, leg. L. Papinutti \& G. Rolón (BAFC 51932); Chilecito, 2909'11.20"S 67²9'34.18” W, abundant, gregarious, on leaf and particulated debris under Prosopis sp., 15.IV.2009, leg. L. Papinutti \& G. Rolón (BAFC 51933); Chamical, 30²0'18.74"S 66²0'23.79” W, on leaf litter of L. divaricata, 2.IV.2007, leg. L. Papinutti \& G. Rolón (BAFC 51934); $30^{\circ} 22^{\prime} 21.10^{\prime \prime} \mathrm{S} 66^{\circ} 17^{\prime} 03.90^{\prime \prime} \mathrm{W}$, on leaf litter of Prosopis sp., 2.IV.2007, leg. L. Papinutti \& G. Rolón (BAFC 51935).
}

Comments- As Soto \& Wright (2000) stated, G. glaucescens resembles small basidiomes of G. striatum; however, that species lacks the ring-like apophysis and has larger distinctly ornamented spores. Another similar species found in La Rioja is G. parvistriatum, which can be distinguished by larger basidiome size, larger spores with a less densely distributed ornamentation, and a subglobose, flattened, or ovoid endoperidial body. The G. parvistriatum stipe is 
much longer and darker than in G. glaucescens. Geastrum minimum also shows similarities but differs from G. glaucescens in its a strongly arched exoperidium, fibrillose peristome, less pruinose endoperidial surface, conspicuous apophysis, and larger spore size. This is the first record of G. glaucescens from La Rioja, although Spegazzini's type collection was collected in Buenos Aires province.

Geastrum hieronymi Henn., Hedwigia 36: 211 (1897, as “Geaster").

Figs 1f, 2b

Basidiomes medium sized 30-70 mm wide when fully open; exoperidium splitting from the middle (or deeper in some specimens) into mostly 6-8 acute rays, sometimes revolute, but not hygroscopic; mycelial layer persistent, brown, encrusting debris; fibrous layer light beige (11B3) when denuded; pseudoparenchymatous layer dark brown when dry (8H7); endoperidial body 20-30 mm wide, dirty bronze grey (15C8), subglobose, with a short stalk, asperate; apophysis prominent; peristome not delimited, fibrillose; gleba bordeaux (8L12).

Spores globose, $3.5-4.5 \mu \mathrm{m}$ wide, verruculose.

Specimen EXAMINED- ARGENTINA. LA Rioja: Miranda, $29^{\circ} 20^{\prime} 51^{\prime \prime} \mathrm{S} 67^{\circ} 42^{\prime} 22.16^{\prime \prime} \mathrm{W}$, on abundant leaf litter and twigs of Prosopis sp., 27.III.2008, leg. L. Papinutti \& G. Rolón (BAFC 51936).

Comments-This is the first report of G. hieronymi from La Rioja.

Geastrum aff. lloydianum Rick, Brotéria 5: 27 (1906, as “Geaster lloydianus”). Fig. 2e Basidiomes 35-40 mm wide; exoperidium splitting into 7-9 acute subequal rays, not hygroscopic; mycelial layer encrusted with sand; fibrous layer ochraceous (14G8); pseudoparenchymatous layer umber (8H12), cracking and seceding in places; endoperidial body $15-20 \mathrm{~mm}$ wide, subpedicellate or almost sessile, light beige (5A9), depressed globose, distinctly pitted and roughened but not truly warted or tomentose; apophysis absent; peristome sulcate, conical, acute, concolorous or darker than the endoperidium; gleba umber (7H11).

Spores globose, 3.0-4.0 $\mu \mathrm{m}$ wide, dark brown, finely verruculose.

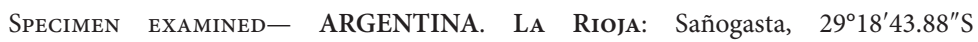
$67^{\circ} 35^{\prime} 37.95^{\prime \prime} \mathrm{W}$, on soil with scarce organic matter, 25.III.2008, leg. L. Papinutti \& G. Rolón (BAFC 51937).

Comments - Our spores agree in size with the cited descriptions, but differ in the type of ornamentation illustrated for this species by Coker \& Couch (1928), which showed sparse minute verrucae. We regard this collection as Geastrum aff. lloydianum, but SEM images of the spores from the type material are needed to clarify this determination. Another key character for this species is the dark endoperidial body (Ponce de Leon 1968); but a recent report of G. lloydianum with a yellowish brown endoperidial surface (Trierveiler-Pereira et al. 2011) suggests that this character can be highly variable. 
Geastrum pampeanum Speg., Anal. Mus. Nac. Bs. As. 6: 192 (1899,

as "Geaster pampeanus") var. pampeanum.

Basidiome $25 \mathrm{~mm}$ wide, saccate; exoperidium membranaceous, delicate, splitting in 5 rays, these helicoidally twisted at tips in the dry state and partially covering the endoperidial body; mycelial layer sand colored, not encrusted with debris; fibrous layer light beige (12C5); pseudoparenchymatous layer dark hazel brown (8H12); endoperidial body $16 \mathrm{~mm}$ wide, sessile, hazel brown at maturity (14B7); peristome fibrillose, delimited, concolorous with the surrounding endoperidial body; apophysis absent; gleba dark brown (8L11).

Spores globose, 4.5-5.5 $\mu \mathrm{m}$ wide, verrucose with regular long $(\leq 1 \mu \mathrm{m})$ columnar verrucae.

Specimen examined- ARgENTINA. La Rioja: Chilecito, $29^{\circ} 09^{\prime} 11.20^{\prime \prime} \mathrm{S}$ $67^{\circ} 29^{\prime} 34.18^{\prime \prime} \mathrm{W}$, solitary, on leaf and particulate debris under Prosopis sp., 20.II.2006, leg.

L. Papinutti (BAFC 51939).

COMments - This is the first record of this variety from La Rioja province.

Geastrum pampeanum var. pallidum Speg., Anal. Mus. Nac. Bs. As. 6: 192 (1899, as "Geaster pampeanus var. pallida").

Mature basidiomes 12-29 mm wide, saccate; exoperidium non-hygroscopic splitting into about 5-10 rays; mycelial layer, slightly encrusted with fine debris; fibrous layer creamy white (2A1); pseudoparenchymatous layer dark beige (8E12); endoperidial body 6-10 $\mathrm{mm}$ wide, sessile, brown at maturity (7C10); peristome fibrillose, delimited, slightly conic but depressed in dry state, concolorous with the surrounding endoperidial body; apophysis absent; gleba dark beige (8C11).

Spores globose, 3.2-4.5 $\mu \mathrm{m}$ wide, verrucose with conical to columnar verrucae.

Specimen EXAMINED- ARGENTINA. LA Rioja: Chilecito, 2909'11.20"S $67^{\circ} 29^{\prime} 34.18^{\prime \prime} \mathrm{W}$, gregarious, on leaf and particulate debris under Prosopis sp., 20.II.2006, leg. L. Papinutti (BAFC 51938).

Comments-This is the first record of this variety from La Rioja province.

Geastrum parvistriatum J.C. Zamora \& Calonge, Bol. Soc. Micol.

Madrid 31: 140 (2007).

FIGs 1d, 2d

Mature basidiomes 20-40 mm wide; exoperidium non-hygroscopic, arched, splitting into 8-11 subequal, acute rays; mycelial layer encrusted with abundant debris; fibrous layer sand colored (12D6); pseudoparenchymatous layer brown (7C9), smooth, peeling off to expose the fibrous layer; endoperidial body 8-15 mm wide, stalked, grey to lead (7C7), smooth and always pruinose; stalk 1.5-2.5 mm high, dark brown; apophysis visible in some basidiomes; peristome conical, plicate-sulcate, well delimited and darker than the endoperidium; gleba brown (8C10). 
Spores globose, 4.3-5.7 $\mu \mathrm{m}$ wide, verrucose with long verrucae that are frequently coalescent at their apices.

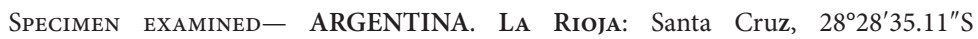
$67^{\circ} 41^{\prime} 54.45^{\prime \prime} \mathrm{W}$, on abundant Prosopis sp. leaf litter, 27.III.2008, leg. L. Papinutti \& G. Rolón (BAFC 51940).

Comments-There are no differences between the accurate description of Zamora \& Calonge (2007) and our material. Our collections were also made on sandy soil, as were the Spanish type material. This is the first report of G. parvistriatum from the Americas, although G. striatum (and perhaps G. schmidelii) specimens there should be re-evaluated in light of Zamora \& Calonge (2007).

Geastrum rufescens Pers., Syn. Meth. Fung.: 134 (1801).

Basidiome medium sized, $25 \mathrm{~mm}$ wide; exoperidium non-hygroscopic, arched to saccate, splitting from the middle into 8 rays with light margins; mycelial layer encrusted with abundant debris; fibrous layer whitish to pale beige (13D5) only visible in the denuded margins of the rays; pseudoparenchymatous layer becoming brownish in age (14I9); endoperidial body $10 \mathrm{~mm}$ wide, globose to depressed globose, light brown (14E6) when dry; stalked, apophysis present, peristome fibrillose, not delimited, neither protruding nor thickened; gleba dark brown (8L6).

Spores globose, 3.5-5.0(-6.0) $\mu \mathrm{m}$ wide, verrucose with long columnar verrucae; capillitial hyphae thick walled.

Specimen EXAMINED- ARGENTINA. LA RioJa: Chilecito, 2909'11.20"S $67^{\circ} 29^{\prime} 34.18^{\prime \prime} \mathrm{W}$, on abundant Prosopis sp. leaf litter under Ephedra triandra, 21.II.2006, leg. L. Papinutti \& G. Rolón (BAFC 51941).

Comments-Although our collection contains just one specimen, the perfectly preserved basidiome exactly fits the descriptions cited above. Soto \& Wright (2000) have already reported G. rufescens from Buenos Aires province, and this is the first report of the species from La Rioja.

Geastrum saccatum Fr., Syst. Mycol. 3(1): 16. (1828, as "Geaster saccatus"). Fig. 1e

Basidiomes typically small though some are medium sized, 19-31 mm wide; exoperidium splitting to about the middle into 6-8(-12) rays of variable shape, often recurved under the whole basidiome; mycelial layer whitish when not covered with debris; fibrous layer beige (14K9); pseudoparenchymatous layer at first white to grey, but soon turning beige to almost dark brown (8H10), relatively thick, papery, sometimes with longitudinal cracks in older specimens, peeling off at the margins with age; endoperidial body (3.5-)5-20(-24) mm wide, globose to depressed globose, sessile or subsessile, pale grey to light beige (14A5) smooth; apophysis lacking; peristome finely fibrillose, mammiform 
to almost flat, delimited, concolorous or darker than the endoperidium and sometimes surrounded by a light colored zone; gleba brown (8H9).

Spores globose, 4.5-6.0 $\mu \mathrm{m}$ wide, ornamented with short columnar verrucae (some apically coalescent).

Specimens EXAMined- ARGENTINA. LA Rioja: Miranda, 29 20'45.54"S 67²' 22.16"W, on Prosopis sp. leaf litter, 27.III.2008, leg. L. Papinutti \& G. Rolón (BAFC 51942, 51944); Sañogasta, $29^{\circ} 18^{\prime} 43.88^{\prime \prime} \mathrm{S} 67^{\circ} 35^{\prime} 37.95^{\prime \prime} \mathrm{W}$, on finely particulated debris, 27.III.2008, leg. L. Papinutti \& G. Rolón (BAFC 51943).

Comments - Although collected in the same locality, the endoperidium color differs in G. saccatum BAFC 51944 and BAFC 51942. Nevertheless, Sunhede (1989) described this character as highly variable in this species. This is the first record of G. saccatum from La Rioja province.

Geastrum schmidelii Vittad., Monog. Lycoperd.: 13. (1842, as “Geaster").

Expanded basidiomes 18-28 mm wide; exoperidium arched, splitting in 10-12 slightly hygroscopic subequal revolute rays; mycelial layer encrusting debris, peeling off in aged specimens; fibrous layer light colored (13B4); pseudoparenchymatous layer brown (7A9), peeling off irregularly; endoperidial body stalked, globose, papery to finely pruinose, grey to brown (7C9), stalk up to $2.5 \mathrm{~mm}$, often laterally compressed; apophysis reduced; peristome delimited, plicate, conic, darker than the surrounding endoperidium; gleba cottony, brown (8L7).

Spores globose, 4.5-7.0 $\mu \mathrm{m}$ wide, verrucose.

SPECIMEN EXAMINED- ARGENTINA. LA RioJA: Sañogasta, $29^{\circ} 18^{\prime} 51.43^{\prime \prime} S$ $67^{\circ} 35^{\prime} 37.36^{\prime \prime} \mathrm{W}$, on abundant leaf litter of diverse herbaceous plant species, 27.III.2008, leg. L. Papinutti \& G. Rolón (BAFC 51945).

Comments-Although the collected material (BAFC 51945) matches the description of Sunhede (1989), some expanded basidiomes exceed the upper limit indicated in his work and in Bates (2004). This is the first record of G. schmidelii for La Rioja province.

\section{Acknowledgments}

We wish to express our gratitude to Dra. María M. Dios and Dr. Scott T. Bates for reviewing the manuscript and offering useful comments. We thank Guillermo Rolón for the technical assistance with the figures. This study was supported by a grant from Consejo Nacional de Investigaciones Científicas y Técnicas (CONICET) and Universidad de Buenos Aires, Argentina.

\section{Literature cited}

Bates ST. 2004. Arizona members of the Geastraceae and Lycoperdaceae (Basidiomycota, Fungi). Masters thesis. Arizona State University, Tempe.

Calonge FD. 1998. Gasteromycetes, I. Lycoperdales, Nidulariales, Phallales, Sclerodermatales, Tulostomatales. Flora Mycologica Iberica. Ed. J. Cramer. 271 p. 
Calonge FD, Mata M, Carranza J. 2005. Contribución al catálogo de los Gasteromycetes (Basidiomycotina, Fungi) de Costa Rica. Anales del Jardín Botánico de Madrid 62: 23-45. http://dx.doi.org/10.3989/ajbm.2005.v62.i1.26

Coker WC, Couch JN. 1928. The Gasteromycetes of the Eastern United States and Canada. Chapel Hill, The University of North Carolina Press.

Domínguez de Toledo LS. 1989 Contribución al conocimiento de Gasteromycetes del centro de Argentina. Doctoral Dissertation. Universidad Nacional de Córdoba, Córdoba.

Leite AG, Calonge FD, Baseia IG. 2007. Additional studies on Geastrum from northeastern Brazil. Mycotaxon 101: 103-111.

Maerz A, Paul MR. 1930. Dictionary of color, 1st edition. McGraw Hill Co, New York.

Ponce de León P. 1968. A revision of the family Geastraceae. Fieldiana Bot 31: 302-349.

Roig A. 1998. Vegetación de la Patagonia. Colección Científica INTA 8: 48-166.

Roig-Juñent S, Flores G, Claver S, Debandi G, Marvaldi A. 2001. Monte Desert (Argentina): insect biodiversity and natural areas. Journal of Arid Environments 47: 77-94. http://dx.doi.org/10.1006/jare.2000.0688

Soto M, Wright JE. 2000. Taxonomía del género Geastrum (Basidiomycetes, Lycoperdales) en la provincia de Buenos Aires, Argentina. Boletín de la Sociedad Argentina de Botánica 34: 185-202.

Sunhede S. 1989. Geastraceae (Basidiomycotina) morphology, ecology, and systematics with emphasis on the North European species. Synopsis Fungorum 1: 1-534.

Trierveiler-Pereira L, Silva AC, Baseia IG. 2009. Notes on gasteroid fungi of the Brazilian Amazon rainforest. Mycotaxon 110: 73-80. http://dx.doi.org/10.5248/110.73

Trierveiler-Pereira L, Calonge FD, Baseia I. 2011. New distributional data on Geastrum (Geastraceae, Basidiomycota) from Brazil. Acta Botanica Brasilica 25: 577-585.

http://dx.doi.org/10.1590/S0102-33062011000300010

Zamora, J.C.; Calonge, F.D. (2007). Geastrum parvistriatum, una nueva especie encontrada en España. Bol. Soc. Micol. Madrid 31: 139-149. 